\title{
Monitoring system and in situ conservation of endemic and threatened Beta patula Aiton populations in Madeira Region
}

\author{
H. Nóbrega • G. Freitas • M. A. Zavattieri • C. Ragonezi (ib) L. Frese • \\ M. A. A. Pinheiro de Carvalho
}

Received: 22 January 2020/ Accepted: 23 September 2020/Published online: 3 October 2020

(C) Springer Nature B.V. 2020

\begin{abstract}
Madeira Archipelago is a hotspot for crop wild relatives (CWR) of crop cultures. Some of these CWR are present in very specific environments, such as, in Ponta de São Lourenço or Desertas Islands. One such species is Beta patula Aiton, a Critically Endangered species which belongs to the Gene Pool $1 \mathrm{~b}$ of cultivated beets. A continuous effort has been developed for its ex situ conservation through the storage of accessions (ISOP2512 and ISOP1911) in the ISOPlexis GeneBank at the University of Madeira.
\end{abstract}

H. Nóbrega - G. Freitas - M. A. Zavattieri .

C. Ragonezi $(\bowtie)$ - M. A. A. P. de Carvalho ISOPlexis Center, University of Madeira, Campus da Penteada, 9020-105 Funchal, Portugal

e-mail: cazi04@hotmail.com

\section{A. Zavattieri}

Biology Department, Colégio da Mitra, University of Évora, Ap. 94, 7002-554 Évora, Portugal

M. A. Zavattieri

Institute of Earth Sciences (ICT), Colégio Luís António Verney, University of Évora, Rua Romão Ramalho 59. 7002-554, Évora, Portugal

L. Frese

Julius Kühn-Institut (JKI), Bundesforschungsinstitut für Kulturpflanzen, Institut für Züchtungsforschung an landwirtschaftlichen Kulturen, Erwin-Baur-Str. 27, 06484 Quedlinburg, Germany

M. A. A. P. de Carvalho

Faculty of Life Sciences, University of Madeira, Campus da Penteada, 9020-105 Funchal, Portugal
Simultaneously, a series of studies have been carried out to understand the species' ecogeographic and ecological requirements, to validate populations' boundaries and sizes, and to establish population dynamics. This study includes a complete floristic survey at the $B$. patula locations of, Desembarcadouro islet (DI) with 12 (DI1-DI12) sampling sites, and Chão islet (CI) with 3 (CI1-CI3). Several Biodiversity indices were calculated for these locations. Plot DI3 exhibited the highest values for Corrected Evenness $\left(\mathrm{E}^{\prime}=0.77 \pm 0.07\right)$, ShannonWeaver Diversity Index $\left(\mathrm{H}^{\prime}=2.48 \pm 0.12\right)$, and Hill's Index $\left(\mathrm{N}_{2}=4.47 \pm 0.72\right)$, with a total sum of 306 individuals of $B$. patula. The demographic status of B. patula populations in DI and CI was determined yearly between 2014 and 2018. The results show an average population size of 16,906 and 2917 plants, respectively. These data will be used for the establishment of a protocol to monitor and manage a genetic reserve for B. patula and other CWR. By doing so, our work will contribute to the implementation of the European genetic reserve network. 


\section{Graphic abstract}
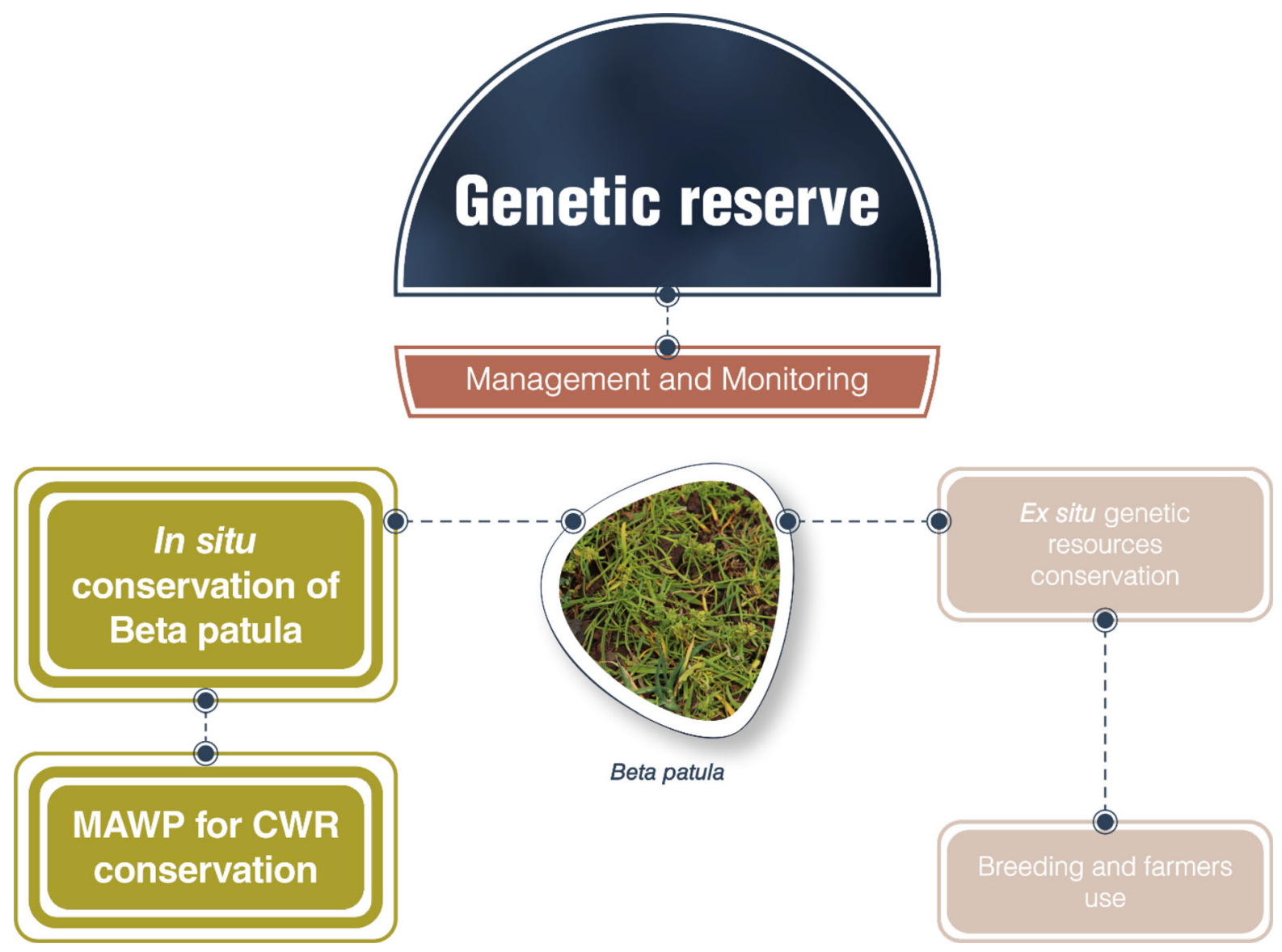

Keywords CWR - Amaranthaceae $\cdot$ Madeira Archipelago $\cdot$ Population size $\cdot$ Biodiversity indices . Species richness $\cdot$ Wild beets

\section{Introduction}

Mankind started to domesticate wild species with the emergence of agriculture (Harlan 1992; Heywood et al. 2005; Fuller et al. 2014; Kantar et al. 2017). Since then, crop wild relatives (CWR) continued to play an important role in plant breeding and the development of improved crop varieties as a condition sine qua non of performant and food security, and crop production. The last 60 years have been rich in examples of the use of genetic resources available in the CWR, for the improvement of the crop cultures (Hajjar and Hodgkin 2007; Dwivedi et al. 2008; Nevo and Chen 2010; Foolad and Panthee 2012; Hufford et al. 2013; Dempewolf et al. 2017; Zhang et al. 2017). Wild species continue to evolve in their natural habitats and develop traits of interest to breeders and farmers (Warschefsky et al. 2014; Brozynska et al. 2015). In the past century, more than $80 \%$ of beneficial traits conferred by CWR genes were related to pests and disease resistance (Prescott-Allen and PrescottAllen 1986), and in recent research more traits are being found (Eizenga et al. 2009; Brozynska et al. 2015; Seiler et al. 2017; Nair 2019). The use of molecular techniques has greatly increased the number of genetic traits available for crop genetic improvement. Genes from over 60 wild plant species have been used to broaden the basis of 16 main food crops breeding pools, contributing to more than 100 beneficial traits, including pest, disease, and abiotic stress resistance (Hajjar and Hodgkin 2007; Dwivedi et al. 2008). In sugar beet (Beta vulgaris L. 
ssp. vulgaris) one of the most important crops in Europe, that accounts for $20 \%$ of the global sugar production (Monteiro et al. 2018), improvement has been developed to increase productivity, sugar content, or other desirable traits (Heijbroek et al. 1983; Biancardi et al. 2012; Capistrano-Gossmann et al. 2016; Stevanato et al. 2019; Pegot-Espagnet et al. 2019). In recent work, Monteiro et al. (2018) pointed out the introgression of traits from CWR for decreasing biotic stresses constraints in sugar beets, namely using Beta and Patellifolia species, both having disease resistance characteristics. More specifically, the beet CWR contributed to the breeding of sugar beet varieties, adding genes for resistance to biotic and abiotic stresses (Luterbacher et al. 2004; Biancardi et al. 2012; Capistrano-Gossmann et al. 2016). The source of these genes was obtained from accessions of CWR populations (Hajjar and Hodgkin 2007; Capistrano-Gossmann et al. 2016) showing the importance of their in situ and ex situ conservation.

The Macaronesia region holds high levels of endemicity, including many CWR with a genetic singularity (Pinheiro de Carvalho et al. 2016). Maxted et al. (2006) defined CWR as "a wild plant taxon that has an indirect use derived from its relatively close genetic relationship to a crop; this relationship is defined in terms of the CWR belonging to Gene Pools 1 or 2 , or taxon groups $1-4$ of the crop". These species groups include the wild ancestor(s) or relatives of crops, that could belong, according to Maxted et al. (2006) to TG1b to TG4 depending on the specific case. Vincent et al. (2019) analyzed the worldwide distribution of 1261 CWR species of 167 major crop genepools, to determine key geographical areas allowing the in situ conservation of these important genetic resources to ensure the climatic adaptation of crops and food systems security and production. 150 sites were identified as being able to promote the in situ conservation of $65.7 \%$ of these CWR. Among sugar and vegetable crops Beta patula Aiton with less than 4 occurrences and more than $50 \%$ of genetic diversity inside protected areas was considered adequate for in situ genetic conservation (Vincent et al. 2019). In Portugal, there are 2319 taxa (including subspecies and varieties) of CWR and wildharvested plant (WHP) which is about $77 \%$ of the total Portuguese flora. From these, around $97.5 \%$ of the taxa are CWR (2262 taxa) (Brehm et al. 2008). Specifically, Madeira Archipelago is a CWR diversity hotspot and holds several CWR of crops that are prioritized according to annex I of the International Treat of Genetic Resources for Agriculture and Food (FAO 2009). Beta patula is a suitable CWR species to the establishment of a genetic reserve in the context of the European Cooperative Programme for Plant Genetic Resources (ECPGR) concept for in situ conservation in Europe (Pinheiro de Carvalho et al. 2012; Kell et al. 2012; Maxted et al. 2015).

Madeira Archipelago belongs to the Macaronesia (Fig. 1a), a biogeographic region composed of four Oceanic Archipelagos. At least 430 CWR occur in the archipelago's flora including wild species of the genus Beta and Patellifolia (Pinheiro de Carvalho et al. 2016). This subfamily is well represented in the western Mediterranean region and all Macaronesia by these two genera (Romeiras et al. 2016).

Lange et al. (1999) divided the Beta vulgaris L. subsp. vulgaris into four groups, namely the cultivar groups Leaf Beet, Garden Beet, Fodder Beet, and Sugar Beet. According to Harlan and De Wet (1971) genepool (GP) concept and its application proposed by Frese (2003, 2010), Beta patula Aiton belongs to section Beta, to the GP1b. The following beet CWR, Arcang., Beta macrocarpa Guss., Beta patula Aiton, Patellifolia patellaris (Moq.) A.J. Scott, FordLloyd \& J.T. Williams, Patellifolia procumbens (C. Sm.) A.J. Scott, Ford-Lloyd \& J.T. Williams and Patellifolia webbiana (Moq.) A.J. Scott, occur in the Macaronesian region (Frese et al. 2019).

Four beet CRW are presently distributed in the Madeira Archipelago in specific environments (Fig. 1b): Madeira, Desertas, Porto Santo, and Selvagens Islands, namely $B$. vulgaris subsp. maritima, $B$ macrocarpa, $B$. patula, and $P$. patellaris. $B$. patula is a rare endemic biennial herbaceous species and has already been studied by sugar beet breeders in the 1890s (De Vilmorin 1923). Letschert (1993) noted in his taxonomic study that a type specimen of the species was not available. Besides, neither the exact name of the type location nor the conservation status was known. The lack of information stimulated interest in the species and research work was initiated by Pinheiro de Carvalho et al. (2010).

B. patula grows in dry open coastal areas under saline conditions and is adapted to high irradiation, semi-arid conditions characterized by low rainfall mostly in the fall and dry summer. The geographical 


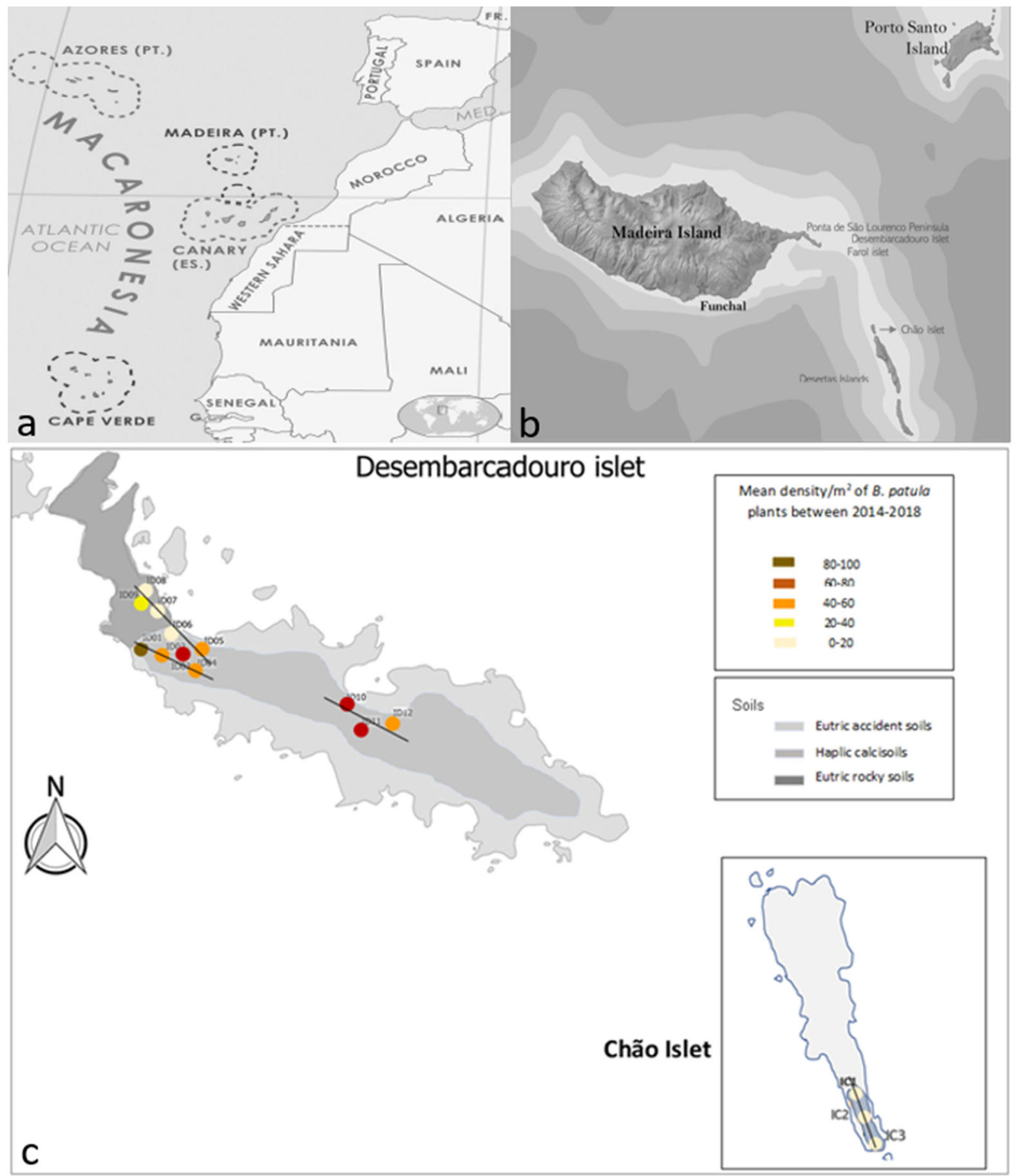


4Fig. 1 Left top a Map with the location and composition of the biogeographic region of Macaronesia, and the Madeira Archipelago (Portugal) in the North Atlantic Ocean. Right top b Map of Madeira Archipelago that comprises two inhabited islands, Madeira and Porto Santo, and two uninhabited Islands groups, the Desertas and the Selvagens islands. Bottom c Areas of occurrence of B. patula are the Desembarcadouro and Chão islets. The figure shows the 15 plots setup in the species occupancy area and considered for its survey and monitoring. Sampling sites DI1-DI12 were distributed along 3 linear transects and CI1-CI3 along one linear transect. In the Desembarcadouro islets the three soil types are represented, according to Pinto et al. (1992). No information on the soil's types in Chão islet exist in the literature. On both islets the colors attributed to the circles for each sampling site correspond to a mean density of $B$. patula plants (plants $\times$ square meter)

distribution of B. patula is restricted to the Madeira Archipelago, with $801 \mathrm{~km}^{2}$, and the occurrence areas to Desembarcadouro islet (DI) and Chão islet (CI), separated apart by about 11 nautical miles $(20 \mathrm{~km})$ (Fig. 1b) (Pinheiro de Carvalho et al. 2010). The DI covers an area of $0.46 \mathrm{~km}^{2}$, while the CI covers an area of $0.50 \mathrm{~km}^{2}$. The occurrence area of B. patula is less than $1.0 \mathrm{~km}^{2}$, being $0.12 \%$ of the species geographical distribution, and the extent of its occupancy is estimated in less than $0.08 \mathrm{~km}^{2}$, being $8.33 \%$ of the species occurrence area. This narrow species distribution, occurrence and occupancy, population fragmentation, and ecological conditions lead to extreme fluctuations of population sizes, that can reach few individuals. Therefore B. patula has been classified as a Critically Endangered species by the International Union for Conservation of Nature (IUCN) in the Red List of Threatened Species (Carvalho et al. 2011).

Previously, a set of initial field missions and surveys allowed to confirm the species occurrence, estimate the occupancy areas, and establish a $B$. patula genetic diversity and population baseline, with a size ranging between 2700 and 5000 specimens in DI and between 250 and 660 individuals in CI (Pinheiro de Carvalho et al. 2010; Frese et al. 2012; Pinheiro de Carvalho et al. 2012). The total population size appeared to be narrow and less than the Minimum Viable Population (MVP) size which is needed by any species to generate novel genetic variation and adaptive potential (for MVP estimation see Traill et al. 2010). Therefore, a strategy and a management plan for in situ conservation of $B$. patula diversity were proposed to local authorities (Frese and Pinheiro de Carvalho 2010; Pinheiro de Carvalho and Frese
2011). This action plan inter alia foresaw the development of a monitoring program required to evaluate plant diversity and detect any significant decline of the population viability, which would trigger conservation actions. The ultimate goal of this plan is to establish a "Beta patula Aiton genetic reserve" (Pinheiro de Carvalho and Frese 2011) in the protected areas of Ponta de São Lourenço and Desertas Islands.

Next to political and legal reasons, from European Union Habitats Directive (1992) and regulations by Madeira authorities, scientific and pragmatic arguments call for improved conservation actions. $B$. patula shows resistance variation for the Beet Mild Yellowing Luteovirus (BMYV) (Schliephake et al. 2010). In sugar beet fields the virus is mainly transmitted by the green peach aphid Myzus persicae (Sulzer, 1776) (Schliephake et al. 2000) and decreases the sugar yield by $18-27 \%$ (Stevens et al. 2004). The spread of BMYV can be controlled by combatting the aphid vectors with insecticides applied either as a seed treatment or as foliar sprays (Dewar et al. 1996). Due to the European Union ban of neonicotinoids in sugar beet production, which came into force, sugar beet growers lost the most important control means for virus yellowing diseases (Hauer et al. 2017) in the growing season of the year 2019. Selection of BMYV tolerant breeding lines started (Luterbacher et al. 2004) but since virus yellowing resistance is a complex trait (Biancardi et al. 2012), work should involve all suitable genetic resources such as $B$. patula.

To face the devastating impact of climate change and the and disappearance of extensive areas of biological diversity as the world population increase, taking action to conserve CWR has become a high priority (Maxted et al. 2010). The European genetic reserve network is still in its planning phase (Maxted et al. 2015). Areas with priority taxa or high density of CWR were identified, using a multiple taxon, floristic, or ecogeographic approaches and suggested as most appropriate sites for in situ CWR conservation (Maxted et al. 1997; Iriondo et al. 2008; Kell et al. 2012; Parra-Quijano et al. 2012). Both DI and CI sites were identified as target genetic reserve sites based on the presence of priority taxa, e.a. B. patula, its genetic singularity, and high plant diversity, that allows acting as an umbrella species for other CWR and endemic species in the area (for umbrella species definition see Roberge and Angelstam 2004). 
The main objective of the present work was to use the 5-year monitoring data to investigate the population structure and dynamics of B. patula. For that, a first assessment of the species situation was made, where the occupancy and specimens' spatial distribution in populations were verified. The habitat, ecological conditions, and the state of the ecosystem in these areas were described. Finally, the current and potential threats for the species were surveyed aiming to reassess the constrains for species conservation according to IUCN criteria (Pinheiro de Carvalho et al. 2010). Based on this prior analysis, and a management and monitoring plan (Frese and Pinheiro de Carvalho 2010; Pinheiro de Carvalho and Frese 2011), a strategy was outlined, which implied yearly ecosystem monitoring and B. patula populations behavior. A yearly population census was carried out to determine if the species is in equilibrium or if it undergoes fluctuations that may jeopardize its conservation and survival and to generate a baseline for future periodic monitoring activities in the B. patula genetic reserve. Additionally, ex situ preservation measures were taken to ensure the conservation of the genetic diversity of the populations. Ultimately, the suitable places for the designation of the genetic reserve based on the size and number of specimens and ecosystem equilibrium were determined.

\section{Materials and methods}

The procedures applied to the study and assessment of the habitat status (soil, weather, species composition) and the B. patula population census and monitoring for 5 years are described. The geographic and biological terms used in this work are defined as follows:

- Region: A larger area such as the Madeira Archipelago of Macaronesia.

- Distribution area: Total area where the target species is known to exist.

- Occurrence: A geographic unit and part of the distribution area where the target species occurs.

- Occupancy: area settled by the target species, which is usually composed of an assemble of plots, where population individuals grown.

- Population: a reproductively coherent group of specimens of the target species, isolated from another coherent group by a geographic barrier.
- Plot: marked, fixed area placed in selected sites where the target species is growing and used for monitoring and census purposes.

- Quadrat: area of $1 \mathrm{~m}^{2}$ established inside the plots.

\section{Study area}

The study areas were the two occurrence sites of Beta patula, e.a. Desembarcadouro islet (DI), and Chão islet (CI) in the Madeira Archipelago was previously described by Pinheiro de Carvalho et al. (2010, 2012) (Fig. 1). Both are part of the Natura 2000 network (https://ec.europa.eu/environment/nature/natura2000/ index_en.htm). Records on the environmental conditions, the floristic composition of the areas as well as the pattern of spatial distribution and the abundance of B. patula were recorded repeatedly between 2014 and 2018.

\section{Environmental data}

Environmental data were obtained from the nearest weather station to B. patula distribution area. The soil conditions referred to in this study have already been published by Pinheiro de Carvalho et al. (2012). Soil types were established using Madeira's island soil chart (Pinto et al. 1992) and the FAO soil classification (FAO/UNESCO 1988).

\section{B. patula population monitoring and floristic survey}

The boundaries of B. patula populations and occupancy were established using the methodology described in Pinheiro de Carvalho et al. (2010). Fifteen plots $(4 \times 4 \mathrm{~m}$ size $), 12$ in DI from DI01 to DI12, and 3 in CI from CI01 to CI03 (Fig. 1c), were established to conduct the $B$. patula census and floristic survey. Plots were placed along three transects in DI and one transect in CI, with a minimum distance of approximately $50 \mathrm{~m}$ between each other. The plot area was chosen as it has a good resolution for herbaceous and small bush plants, been that the floristic composition falls in such criteria. Each plot was divided into subsets of $1 \mathrm{~m}^{2}$ resulting in 16 quadrats (Fig. 1c) and marked with a wooden stake in each corner. The plot boundaries were delineated with the assistance of a GPS and the surface of each plot 
calculated. The total occupancy area of B. patula in the DI and CI both populations was determined as the sum of the individual plots.

The methodology proposed by Iriondo et al. (2008) was used to organize $B$. patula population monitoring. Four quadrats were randomly determined in each year using the Research Randomizer Generated Numbers software (Urbaniak and Pious 2011). In each selected quadrat all plant species were identified, recorded, and counted once per year. The counting was repeated and the mean value of the two counts calculated. If both counts differed strongly a re-count was made. In the case of $B$. patula only adults, reproductive plants were counted. The census information was gathered in a Dataset following the GBIF guidelines for publication (Nóbrega et al. 2020).

In the quadrats all plant species record were identified according to Aguiar et al. (2004) and Pires and Fontinha (2008), and sampled specimens labeled using the nomenclature of The Plant List (http://www. theplantlist.org/). The status (endemic, native, etc.) of each species was determined according to Borges et al. (2008).

\section{Statistical methods}

Data on the species census and floristic survey were used to analyze the $B$. patula populations' effective size, demographic development, and spatial distribution, as well as companion species diversity. For species population census and size estimation, we assume that the species is composed of only two populations, corresponding to the sites of occurrence of $B$. patula. The effective population size was calculated using the formula.

$\mathrm{N}=(\mathrm{A} / \mathrm{a}) * \mathrm{n}$

where A, corresponds to the total area of occupancy, a, the total quadrat area, $\mathrm{n}$, a total of all counts.

Census data for DI and CI populations were used to calculate the effective population size $(\mathrm{N})$ whereby $\mathrm{n}$ is the generation number, and the $\mathrm{N}$ value presented in Table 3 in the average size of 5 years census. The effective population size is largely determined by the breeding system as well as the sex ratio within the reproductive population of generation $\mathrm{n}$ (Wricke 1972). The minimal viable size population $(\mathrm{Ne})$ was calculated by Wricke formula, as the harmonic mean of the estimated specimen's number in the occupancy area, for 5 years. We assume that the B. patula is a biennial, preferentially self-pollinating species, that reproduce once in 2 years and that the harmonic mean presented in Table 2 is a good estimator of Ne. Nevertheless, additionally, a minimal viable size population $\left(\mathrm{Ne}^{\prime}\right)$ as a $1 / 50$ ratio of effective population size was also calculated according to Iriondo et al. (2008).

The following indexes: Sample Completeness (SC), Shannon-Wiener Diversity Index $\left(\mathrm{H}^{\prime}\right)$, Corrected Evenness $\left(\mathrm{E}^{\prime}\right)$ index, Hill Index $\left(\mathrm{N}_{2}\right)$ were calculated to determine the richness and conservation status of plant community in the occupancy places of B. patula populations.

The Sample Completeness (SC) (Burnham and Overton 1979) was calculated, using the software available at https://www.mbr-pwrc.usgs.gov/ software/specrich.html. The term species richness is identical to the species diversity and describes the total number of distinct plant taxa in a plant community independently of their abundance (Gregorius and Gillet 2015). In the work presented here, a diversity index is a quantitative measure indicating how many different species exist in a quadrat, and how the species are distributed in the observed plant community.

$S C=\frac{O S R}{E S R} \times 100$

where Observed Species Richness (OSR) - this value is obtained from the direct observation of the total species present in the quadrats and was calculated according to Drozd (2010); Expected Species Richness (ESR)-is an estimated value obtained from the methodology of Burnham and Overton (1979). It considers the number of species with a single observed individual (singletons), species with two observed individuals (doubletons), etc., present in the population.

The values obtained for SC inform us if the sampling effort was enough to characterize the occupancy area. If the SC scores are above $75 \%$, it is considered an effective sampling event. If the value is below $75 \%$ it means the area was not adequately sampled. The Community Ecology Parameter Calculator version 1.0 (Drozd 2010) was used to calculate the OSR and several other diversity indexes.

The Shannon-Wiener Diversity Index $\left(\mathrm{H}^{\prime}\right)$ quantifies the uncertainty in predicting the species identity of an individual that is taken at random from the dataset. If almost all plants within a quadrat belong to one 
species the index of that quadrat is close to zero (Spellerberg and Fedor 2003). $\mathrm{H}^{\prime}$ is the most widely used measure in diversity studies (Hubalek 2000). The formula is given as:

$H^{\prime}=\sum_{i=1}^{S} p_{i} \ln p_{i}=-\sum_{i=1}^{S} L_{n} p_{i}^{p_{i}}$

where $\mathrm{S}$ - species richness (number of species); pithe proportion of species i; $P_{i}=\frac{n_{i}}{N} ; n_{i}$ - the abundance of species $i ; N$-total abundance.

Corrected Evenness $\left(\mathrm{E}^{\prime}\right)$ index was calculated according to Gosselin (2006) and Adams (2009) to analyze the dependence on species richness. The index shows the degree to which individuals are divided among species. Low values indicate that one or few species dominate, while high values indicate a likewise equal distribution of individuals over species (Gosselin 2006; Morris et al. 2014). The corrected evenness is defined as follows:

$E^{\prime}=\frac{H^{\prime}-H_{\min }^{\prime}}{H_{\max }^{\prime}-H_{\text {min }}^{\prime}}$

where

$H_{\text {max }}^{\prime}=\log _{2} S$

$H_{\text {min }}^{\prime}=-\frac{N-S+1}{N} \log _{2} \frac{N-S+1}{N}+\frac{S-1}{N} \log _{2} N$

The Hill Index $\left(\mathrm{N}_{2}\right)$ (Mo 1973), also known as the inverse Simpson index, is a measure of biological diversity that relates species richness and the Simpson Index. There is a series of Hill indices that differ in the order of a $=0,1,2, \ldots$ in which the index is dependent on rare species. $\mathrm{N}_{2}$ estimates diversity effective numbers and obtains high values in datasets of high diversity. $\mathrm{H}^{\prime}$ and $\mathrm{N}_{2}$ strongly correlate with the number of distinct species represented in the dataset and match several additional quality criteria. Compared to $\mathrm{H}^{\prime}$, the $\mathrm{N}_{2}$ tends to depend more on the presence of a few dominant species (Hubalek 2000).

$N_{2}=\frac{1}{\sum_{i=1}^{S} P_{i}^{2}}$

where $S$-species richness, $p_{i}$-the proportion of species $i$.
Patula ex situ conservation

To conserve genetic diversity, DI and CI populations were seed sampled, during the census field missions. Germplasm samples were collected according to genebank standards (FAO 2014) for ex situ conservation. Accessions were included in the germplasm collection of ISOPlexis genebank (http://isoplexis. uma.pt). Sampling was carried out yearly in both islets and duplicate at the Banco Português de Germoplasma Vegetal, INIAV, I.P., Portugal.

\section{Results and discussion}

Description of B. patula occurrence sites

The DI and CI climatic and soil conditions were described previously in Pinheiro de Carvalho et al. (2010). DI soils can be roughly divided into three units: haplic calcisoils, eutric accident soils, eutric rocky soils, and the major soil unit in $\mathrm{CI}$ is haplic calcisoils (Fig. 1c, FAO/UNESCO 1988). Overall, the soils are poor, loamy, and rocky, with low organic matter and moisture content, and high salinity. Soils are slightly acidic to slightly basic, with $\mathrm{pH}$ values ranging between 5.88 and 7.49 (Pinheiro de Carvalho et al. 2010, 2012).

The 5-year climatogram generated for DI and CI was obtained from the nearest weather station (Instituto Português do Mar e Atmosfera from 2014 to 2018) and confirmed the early climate description. The average annual precipitation was $350 \mathrm{~mm}$. The highest value of annual maximal rainfall in the 5 years was less than $460 \mathrm{~mm}$, measured in 2018. The average temperature ranges from 14.6 to $23.5^{\circ} \mathrm{C}$, with a percentage of relative air humidity around $65 \%$. The weather data recorded agreed with the long-term averages. Thus, B. patula grows in sites that can be described as semi-arid. Further, both sites have high exposition to strong marine winds and are found in quite eroded soils.

\section{B. patula population monitoring}

One of this work's goals was to confirm the $B$. patula occupancy area and population boundaries established earlier, and to implement the population monitoring. The population's patchy structure and its 
boundaries as well as the occupancy were confirmed in DI and CI. The total occupancy area was established to be around $0.08 \mathrm{~km}^{2}$, with $0.068 \mathrm{~km}^{2}$ occurring in DI and $0.012 \mathrm{~km}^{2}$ in CI. On CI the species is distributed over one patch in the south end of the islet displaying a small population (Fig. 1c), whereas 3 plots (C13-C15) were established. In DI $B$. patula population is distributed in several patches, that spatially are displayed along three transects passing through the main occupancy areas. In these areas, 12 plots (DI1-DI12) were established.

The population status and sizes were analyzed through the $B$. patula specimen's census survey, using these 15 plots observed between 2014 and 2018. The number of specimens counted within these plots strongly varies (Table 1). The plant density was calculated as the 5-year mean per plot. The highest number of individuals of $B$. patula was recorded in 2017 with 1054 (combined counts on both islets, Fig. 2 and Table 1). In the last year, this number showed a reduction to 842 individuals, due to a sharp fall to only three individuals counted in CI. This kind of fluctuation in population size can naturally occur in wild populations and can be related to cyclical events or have stochastic nature (De Hond et al. 2004).

The averages effective population size $(\mathrm{N})$ was estimated in 16,906 and 2917 plants in DI and CI, respectively (Table 2). New $\mathrm{N}$ values for $B$. patula population size were slightly higher than the values gathered from the AEGRO project (http:// aegro.julius-kuehn.de/aegro/) (DI 2700-5000 and CI 250-660) (Pinheiro de Carvalho et al. 2012). The yearly effective population size was used to determine the size of the Minimum Viable Population (MVP) via harmonic mean (Neh). The Neh was determinate as 11,615 plants for DI and 941 plants for CI (Table 2). Waples (2016) defends that in natural populations the $\mathrm{N}$ should be in the order of magnitude of 5000 individuals to be viable, but this value should depend on plant species and various other factors, such as life cycle and reproduction systems. In Madeira, many native species do not reach such population sizes and seems to have other survival strategies (Alves et al. 2019). Iriondo et al. (2008) defend that the natural population becomes a threat when the number of adult specimens in $\mathrm{N}$ are less than $\mathrm{Ne}^{\prime}$, e.a. 1/50 ratio of $\mathrm{N}$. The $\mathrm{Ne}^{\prime}$ was 1691 plants for DI and 292 plants for CI (Table 2).
The estimated $\mathrm{N}$ of B. patula in DI is 1.5 -folds high than $\mathrm{Ne}_{\mathrm{h}}$ (Table 2). Therefore, species maintain a population size that was over the MVP given by $\mathrm{Ne}_{\mathrm{h}}$, during the census period, except for 2014 and 2015 (data not shown). While in the CI population whereas the $\mathrm{N}$ was 3.0-fold higher than $\mathrm{Ne}_{\mathrm{h}}$, a strong variation in the yearly number of effectives, with the population size $(\mathrm{N})$ becoming lower than $\mathrm{Ne}^{\prime}$ (the MVP according to Iriondo et al. 2008) was observed in 2018. The Ne/N ratio was 0.32 (DI) and $0.69(\mathrm{CI})$, indicating that $\mathrm{N}$ fluctuations in CI were stronger than in DI, as expected. The comparison of these census $\mathrm{N}$ values with early population baseline size (see above) estimated by Pinheiro de Carvalho et al. (2012) presented differences. It's impossible to establish if the differences in $\mathrm{N}$ values of both $B$. patula populations result from less accuracy in first estimations or are originated by natural and/or stochastic population fluctuations. Nevertheless, $\mathrm{N}$ values are higher than the initial estimations of $>50$ adult specimens for DI and CI populations, one of the IUCN criteria used in the classification of B. patula as Critical Endangered (Table 2). So, this last criterion showed a quality improvement. These results demonstrate that it is of fundamental interest to the Natura 2000 site management authorities to understand the factors determining the size fluctuations in both populations. The observed reduction of B. patula population size in CI seems to be linked with extreme weather events and can directly affect population viability $\left(\mathrm{N}<\mathrm{Ne}_{\mathrm{h}}\right.$ and/or $\mathrm{N}<\mathrm{Ne}^{\prime}$ ) provoking its genetic diversity erosion and compromising the acquisition of genetic variability, that could promote the species adaptation to environmental conditions drift.

During the $B$. patula populations, monitoring and census the species soil seed bank was been accessed through the sampling and account the seed in the soil of $1 \mathrm{~m}$. The soil seed counting was on average 2671 and $1173 \mathrm{seed} / \mathrm{m}^{2}$, in ID and IC, respectively (data not shown). Besides ex situ and in situ tests performed to assess the soil seeds viability showed that the germination rate in field conditions was less than $2 \%$ and in laboratory conditions reaches only $10 \%$ (data not shown). These results point to the need to study the environmental factors limiting the $B$. patula seed germination. Also, they point out the importance of ex situ conservation of B. patula, since the germplasm accessions collected, can be used in population 
Table 1 Spermatophytes species surveyed in Desembarcadouro (DI) and Chão (CI) Islets

\begin{tabular}{|c|c|c|c|c|c|c|c|c|c|c|c|c|}
\hline \multirow[t]{2}{*}{ Family } & \multirow[t]{2}{*}{ Species } & \multirow[t]{2}{*}{ Status } & \multicolumn{2}{|c|}{2014} & \multicolumn{2}{|c|}{2015} & \multicolumn{2}{|c|}{2016} & \multicolumn{2}{|l|}{2017} & \multicolumn{2}{|l|}{2018} \\
\hline & & & DI & $\mathrm{CI}$ & DI & CI & DI & CI & DI & CI & DI & $\mathrm{CI}$ \\
\hline \multirow[t]{4}{*}{ Aizoaceae } & Aizoon canariense $\mathrm{L}$. & $\mathrm{n}$ & 0 & 0 & 0 & 0 & 0 & 0 & 0 & 22 & 2 & 0 \\
\hline & Mesembryanthemum crystallinum $\mathrm{L}$. & ip & 213 & 41 & 219 & 51 & 676 & 29 & 1971 & 95 & 3275 & 43 \\
\hline & *Mesembryanthemum nodiflorum L. & $\mathrm{n}$ & 119 & 19 & 27 & 126 & 164 & 3 & 125 & 145 & 208 & 40 \\
\hline & $\begin{array}{l}\text { Tetragonia tetragonoides (Pall.) } \\
\text { Kuntze }\end{array}$ & $\mathrm{i}$ & 8 & 0 & 0 & 0 & 59 & 0 & 44 & 0 & 1 & 0 \\
\hline \multirow[t]{5}{*}{ Amaranthaceae } & $\begin{array}{l}\text { *Bassia tomentosa (Lowe) Maire \& } \\
\text { Weiller }\end{array}$ & $\mathrm{n}$ & 0 & 0 & 0 & 0 & 0 & 0 & 1 & 0 & 0 & 0 \\
\hline & *\#Beta maritima L. & $\mathrm{n}$ & 5 & 0 & 43 & 0 & 0 & 0 & 186 & 0 & 0 & 0 \\
\hline & *\#Beta patula Aiton & END & 256 & 31 & 171 & 17 & 451 & 35 & 976 & 78 & 839 & 3 \\
\hline & $\begin{array}{l}\text { *\#Patellifolia pattelaris (Moq.) A.J. } \\
\text { Scott, Ford-Lloyd \& J.T. Williams }\end{array}$ & $\mathrm{n}$ & 0 & 0 & 19 & 0 & 6 & 0 & 0 & 0 & 0 & 0 \\
\hline & *Suaeda vera Forssk. ex J.F. Gmel & $\mathrm{n}$ & 86 & 8 & 93 & 7 & 107 & 4 & 96 & 8 & 104 & 9 \\
\hline \multirow[t]{5}{*}{ Asteraceae } & $\begin{array}{l}\text { *Andryala glandulosa Lam. subsp. } \\
\text { glandulosa }\end{array}$ & END & 59 & 0 & 1 & 0 & 0 & 0 & 43 & 0 & 206 & 2 \\
\hline & $\begin{array}{l}\text { *Calendula incana subsp. maderensis } \\
\text { (DC.) Ohle }\end{array}$ & $\mathrm{n}$ & 0 & 0 & 0 & 0 & 4 & 0 & 6 & 0 & 43 & 0 \\
\hline & $\begin{array}{l}\text { *Crepis divaricata (Lowe) F.W. } \\
\text { Schultz }\end{array}$ & END & 184 & 4 & 21 & 0 & 23 & 3 & 42 & 64 & 101 & 0 \\
\hline & *Senecio incrassatus Lowe & MAC & 3 & 0 & 0 & 0 & 0 & 0 & 1 & 0 & 0 & 1 \\
\hline & *Sonchus oleraceus L. & $\mathrm{np}$ & 26 & 0 & 0 & 0 & 0 & 0 & 9 & 0 & 94 & 1 \\
\hline \multirow[t]{2}{*}{ Brassicaceae } & *Matthiola maderensis Lowe & END & 36 & 0 & 22 & 0 & 24 & 0 & 7 & 1 & 8 & 1 \\
\hline & $\begin{array}{l}\text { *\#Rapistrum rugosum (L.) All. subsp. } \\
\text { linnaeanum (Coss.) Rouy \& } \\
\text { *Foucaud }\end{array}$ & $\mathrm{n}$ & 3 & 0 & 3 & 0 & 0 & 0 & 6 & 0 & 0 & 0 \\
\hline \multirow[t]{2}{*}{ Caryophillaceae } & *Silene vulgaris (Moench) Garcke & $\mathrm{n}$ & 15 & 0 & 19 & 0 & 9 & 0 & 28 & 0 & 14 & 0 \\
\hline & $\begin{array}{l}\text { *Spergula fallax (Lowe) E.H.L. } \\
\text { Krause }\end{array}$ & $\mathrm{n}$ & 2 & 82 & 0 & 98 & 0 & 0 & 15 & 105 & 2 & 3 \\
\hline Euphorbiaceae & Mercurialis aппиа L. & $\mathrm{n}$ & 0 & 0 & 0 & 0 & 0 & 0 & 2 & 0 & 66 & 0 \\
\hline \multirow[t]{3}{*}{ Fabaceae } & *\#Lotus glaucus Sol. & MAC & 47 & 0 & 17 & 0 & 15 & 0 & 188 & 0 & 281 & 0 \\
\hline & *\#Medicago minima $(\mathrm{L}.) \mathrm{L}$. & $\mathrm{n}$ & 0 & 0 & 0 & 0 & 0 & 0 & 2 & 0 & 30 & 0 \\
\hline & *\#Melilotus sulcatus Desf. & $\mathrm{n}$ & 25 & 0 & 0 & 0 & 4 & 0 & 78 & 0 & 124 & 0 \\
\hline Frankeniaceae & Frankenia laevis L. & $\mathrm{n}$ & 1 & 0 & 0 & 0 & 0 & 0 & 0 & 0 & 0 & 0 \\
\hline Malvaceae & *Malva parviflora $\mathrm{L}$. & $\mathrm{n}$ & 0 & 0 & 15 & 0 & 24 & 0 & 44 & 1 & 4 & 0 \\
\hline \multirow[t]{2}{*}{ Plantaginaceae } & *Plantago coronopus L. & $\mathrm{n}$ & 0 & 251 & 0 & 473 & 0 & 6 & 0 & 100 & 1 & 2 \\
\hline & *Plantago leiopetala Lowe & END & 23 & 0 & 3 & 0 & 3 & 0 & 11 & 0 & 8 & 0 \\
\hline \multirow[t]{3}{*}{ Poaceae } & *\#Hordeum marinum Huds. & $\mathrm{n}$ & 0 & 0 & 0 & 0 & 0 & 0 & 0 & 17 & 0 & 12 \\
\hline & $\begin{array}{l}\text { Lolium rigidum Gaudin subsp. } \\
\text { rigidum }\end{array}$ & $\mathrm{i}$ & 0 & 97 & 0 & 0 & 0 & 0 & 13 & 85 & 49 & 12 \\
\hline & $\begin{array}{l}\text { *\#Phalaris maderensis (Menezes) } \\
\text { Menezes }\end{array}$ & MAC & 155 & 0 & 31 & 0 & 2 & 0 & 77 & 0 & 254 & 0 \\
\hline Polygonaceae & $\begin{array}{l}\text { Rumex bucephalophorus L. subsp. } \\
\text { canariensis (Steinh.) Rech.f. }\end{array}$ & MAC & 1 & 0 & 0 & 0 & 0 & 0 & 0 & 0 & 0 & 0 \\
\hline
\end{tabular}


Table 1 continued

\begin{tabular}{|c|c|c|c|c|c|c|c|c|c|c|c|c|}
\hline \multirow[t]{2}{*}{ Family } & \multirow[t]{2}{*}{ Species } & \multirow[t]{2}{*}{ Status } & \multicolumn{2}{|c|}{2014} & \multicolumn{2}{|c|}{2015} & \multicolumn{2}{|c|}{2016} & \multicolumn{2}{|l|}{2017} & \multicolumn{2}{|l|}{2018} \\
\hline & & & DI & CI & DI & $\mathrm{CI}$ & DI & CI & DI & $\mathrm{CI}$ & DI & CI \\
\hline Xanthorrhoeaceae & *Asphodelus fistulosus L. & $\mathrm{n}$ & 1 & 91 & 26 & 575 & 33 & 469 & 38 & 583 & 61 & 809 \\
\hline
\end{tabular}

The species were classified by their family affiliation and their status between 2014 and 2018. Taxonomic names are in accordance with The Plant List 1.1 (2013-http://www.theplantlist.org/)

END, Endemic to Madeira; Taxa whose natural distribution is restricted to the islands of the Madeira Archipelago and Selvagens; MAC, endemic to Macaronesian; whose natural distribution area only includes Macaronesia (Azores, Madeira, Selvagens, Canaries and Cabo Verde); n, Native; taxa whose natural distribution includes Madeira (Madeira Archipelagos and Selvagens), but which occurs naturally in other territories besides Macaronesia; np, Probably native; taxa considered as native by the most recent authors, but that were considered like species probably introduced by the older authors; ip, Probably introduced; taxa that are considered as introduced by the majority of the consulted authors, but still present some degree of uncertainty as to their status; i, Introduced; Taxa resulting from naturalization after human introduction. The native species that represent CWR are signalized with a (*) and the related with the Annex I of international Treaty with a (\#) data from the ISOPlexis Genebank Documentation System and confirmed by the https://www.cwrdiversity.org/checklist/. Accessed 10 Aug 2020

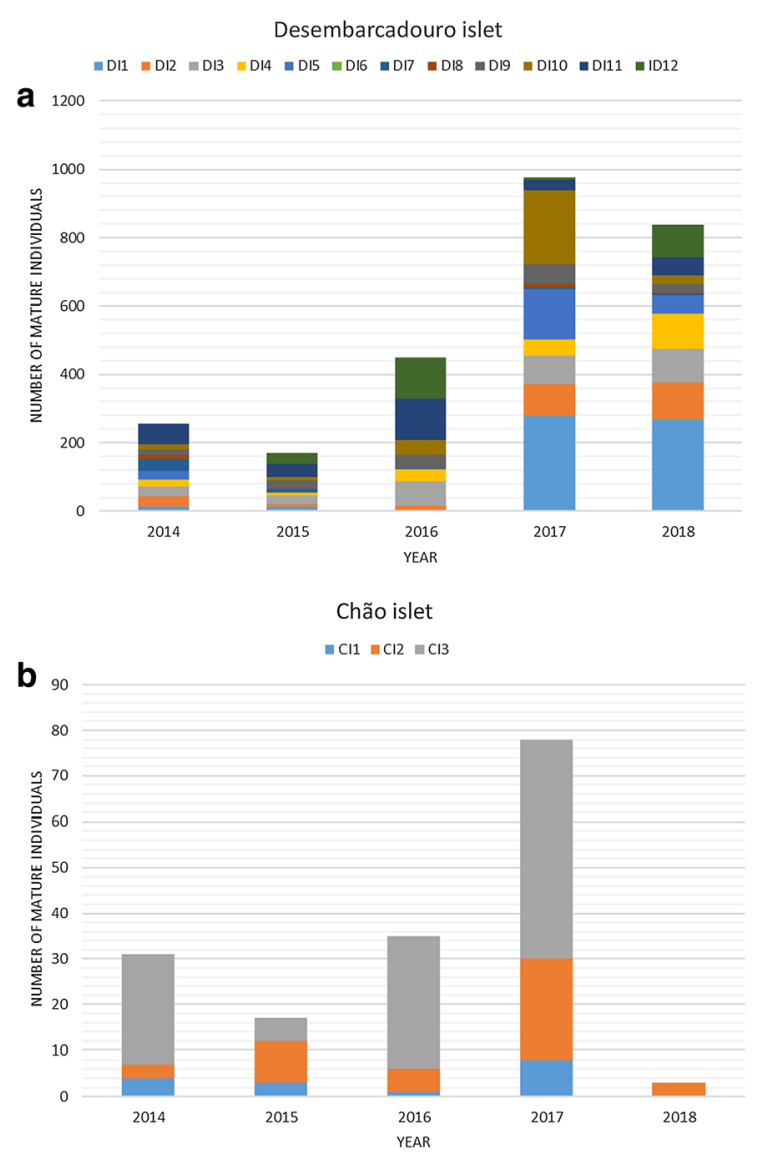

Fig. 2 Spatial and temporal distribution of B. patula of adult individuals considering: a Desembarcadouro samplings sites (DI1-DI12), and b Chão sampling sites (CI1-CI3)
Table 2 Beta patula census, with the determination of population size

\begin{tabular}{lll}
\hline Population size & DI & CI \\
\hline $\mathrm{N}$ & 16,906 & 2917 \\
$\mathrm{Ne}_{\mathrm{h}}$ & 11,615 & 941 \\
$\mathrm{Ne}^{\prime}$ & 1691 & 292 \\
Minimum size & 5873 & 250 \\
Maximum size & 31,078 & 6500 \\
Amplitude variation range & $11,032-14,173$ & $2667-3583$ \\
\hline
\end{tabular}

The actual average effective size population $(\mathrm{N})$, minimum viable size population, calculated as harmonic mean $\mathrm{Ne}_{\mathrm{h}}$, or on base of $\mathrm{Ne} / \mathrm{N}$ ratio $\left(\mathrm{Ne}^{\prime}\right)$ and minimum and maximum population sizes in the Desembarcadouro (DI) and Chão (CI) islet are given. Numbers represents adult individuals

reinforcement once the in situ populations size drops below the MVP or for breeding purposes.

\section{Site floristic characterization}

The species detected in occupancy areas of both $B$. patula populations were presented in Table 1 (species diversity), and in Table 3 (sum of specimens recorded per quadrat, and average values of biodiversity indexes). In the Ponta de São Lourenço, which includes the DI occurrence site of B. patula, the flora is composed of 138 plant taxa including 31 (22.5\%) of endemic taxa. Besides, 203 plant taxa including 51 (25.1\%) of endemic taxa can be found in the Desertas Islands, which includes CI occurrence site (Fontinha 
Table 3 Beta patula census, with the determination of its population size

The table shows the sum of B. patula specimens recorded per quadrant, and average values and corresponding standard deviation of biodiversity indexes calculated to determine the Species Richness (S), Sample Completeness (SC), Corrected Evenness $\left(\mathrm{E}^{\prime}\right)$, Shannon-Weaver Diversity $\left(\mathrm{H}^{\prime}\right)$, Hill's Index $\left(\mathrm{N}_{2}\right)$

*Values in bold show higher values for DI3, DI10 and DI12

\begin{tabular}{lrlllll}
\hline Site & \multicolumn{1}{l}{$\mathrm{N}$} & $\mathrm{S}$ & $\mathrm{SC}$ & $\mathrm{E}^{\prime}$ & $\mathrm{H}^{\prime}$ & $\mathrm{N}_{2}$ \\
\hline DI1 & 578 & $6.40 \pm 2.58$ & $93.33 \pm 0.68$ & $0.66 \pm 0.17$ & $1.74 \pm 0.54$ & $3.00 \pm 1.29$ \\
DI2 & 253 & $5.50 \pm 2.06$ & $87.29 \pm 1.25$ & $0.63 \pm 0.23$ & $1.58 \pm 0.29$ & $2.57 \pm 0.65$ \\
DI3 & 306 & $\mathbf{8 . 8 0} \pm \mathbf{1 . 4 7 *}$ & $92.88 \pm 0.97$ & $\mathbf{0 . 7 7} \pm \mathbf{0 . 0 7} *$ & $\mathbf{2 . 4 8} \pm \mathbf{0 . 1 2} *$ & $\mathbf{4 . 4 7} \pm \mathbf{0 . 7 2 *}$ \\
DI4 & 212 & $5.40 \pm 2.06$ & $91.00 \pm 0.80$ & $0.59 \pm 0.14$ & $1.43 \pm 0.48$ & $2.31 \pm 0.92$ \\
DI5 & 225 & $8.00 \pm 3.79$ & $81.98 \pm 1.80$ & $0.69 \pm 0.13$ & $2.03 \pm 0.61$ & $3.48 \pm 1.05$ \\
DI6 & 0 & $2.40 \pm 0.49$ & $95.00 \pm 0.28$ & $0.54 \pm 0.24$ & $0.68 \pm 0.22$ & $1.42 \pm 0.22$ \\
DI7 & 50 & $3.80 \pm 0.75$ & $92.67 \pm 0.57$ & $0.50 \pm 0.28$ & $1.08 \pm 0.62$ & $2.16 \pm 0.91$ \\
DI8 & 24 & $5.40 \pm 2.15$ & $87.00 \pm 1.08$ & $0.72 \pm 0.13$ & $1.74 \pm 0.54$ & $2.85 \pm 0.87$ \\
DI9 & 165 & $5.20 \pm 0.98$ & $90.83 \pm 0.85$ & $0.53 \pm 0.20$ & $1.30 \pm 0.35$ & $2.12 \pm 0.62$ \\
DI10 & 313 & $7.60 \pm 1.85$ & $89.44 \pm 1.08$ & $\mathbf{0 . 7 6} \pm \mathbf{0 . 1 0} *$ & $2.24 \pm 0.39$ & $\mathbf{4 . 3 2} \pm \mathbf{1 . 3 6}$ \\
DI11 & 302 & $8.67 \pm 1.70$ & $89.56 \pm 1.46$ & $0.65 \pm 0.12$ & $2.24 \pm 0.24$ & $3.63 \pm 0.86$ \\
DI12 & 261 & $\mathbf{9 . 3 3} \pm \mathbf{0 . 4 7 *}$ & $88.14 \pm 1.81$ & $0.66 \pm 0.09$ & $\mathbf{2 . 3 9} \pm \mathbf{0 . 1 9 *}$ & $3.82 \pm 0.80$ \\
CI1 & 16 & $5.80 \pm 1.47$ & $90.29 \pm 0.68$ & $0.55 \pm 0.13$ & $1.56 \pm 0.40$ & $2.44 \pm 0.79$ \\
CI2 & 42 & $7.40 \pm 1.62$ & $93.03 \pm 0.68$ & $0.42 \pm 0.23$ & $1.38 \pm 0.72$ & $2.25 \pm 1.22$ \\
CI3 & 117 & $5.60 \pm 1.02$ & $83.50 \pm 1.37$ & $0.45 \pm 0.24$ & $1.16 \pm 0.59$ & $1.95 \pm 0.79$ \\
\hline
\end{tabular}

and Carvalho 1995; Borges et al. 2008; Pires and Fontinha 2008).

The floristic composition of DI and CI sites, had similarities, due to geographic proximity and similar climate and soil conditions. Plant species belonged to 13 families were shown in Table 1. Thirty-one distinct plant species were recorded during the study; 25 species were found in DI and 12 in CI. Five of these species, excluding the target species, B. patula, were common to both sites and recorded in occupancy areas, namely Mesembryanthemum crystallinum L., Mesembryanthemum nodiflorum L., Suaeda vera Forssk. ex J.F. Gmel, Spergula fallax (Lowe) E.H.L. Krause, Crepis divaricata (Lowe) F.W. Schultz. All species were classified as native or probably native (19 taxa), endemic (9 taxa), and introduced or probably introduced (3 taxa) (Table 1). Among the endemic species, five are specific to Madeira.

The DI flora is part of the Mayteno umbellataeOleion maderensis vegetation series complex (Aguiar et al. 2004; Costa et al. 2012). This vegetation is exclusive to southern rocky cliffs restricted to 0-200 meters above sea level. On the occupancy and sampling areas, two vegetation mosaics from the dry to semi-arid infra-Mediterranean halinotrophyle community stand out: (1) The Calendula maderensisSuaedetum vera (Aguiar et al. 2004; Costa et al. 2012), which is composed of species such as Suaeda vera Forssk. ex J.F. Gmel, Calendula incana subsp. maderensis (DC.) Ohle and Lotus glaucus Sol.; (2) The Senecio incrassati-Mesembryanthemetum cristalini, which is composed of species such as Mesembryanthemum crystallinum L., Mesembryanthemum nodiflorum L., Senecio incrassatus Lowe, Aizoon canariensis L., Tetragonia tetragonoides (Pall.) Kuntze and Spergula fallax (Lowe) E.H.L. Krause (Aguiar et al. 2004).

As shown in Table 1 the DI contributes with more than $80 \%$ of the total endemism's detected in the survey. The abundance of $B$. patula increased between 2014 and 2018. However, there was a little decrease in the number of individuals in the last census year. Also, $C$. incana increased its presence in the plots. For the total number of introduced species, $M$. crystallinum had the highest individuals account among all the species in both islets.

Fifteen native and probably native species were recorded in DI and seven in CI (Table 1). Therefore, they were the major group of plants recorded in both islets. Table 1 shows the number of native plants and the accumulative number of their specimens on both islets per year between 2014 and 2018. Among the most abundant native species are the following: Asphodelus fistolosus and Plantago coronopus in CI, and M. nodiflorum and Sueda vera in DI. Twenty-two native species represent CWR that appear in the same B. patula occupancy areas. According to our survey confirmed by CWR inventory (https:// www.cwrdiversity.org/checklist/) these species 
are: Andryala glandulosa Lam. subsp. glandulosa; Asphodelus fistulosus L.; Bassia tomentosa (Lowe) Maire \& Weiller; Beta maritima L. [Beta vulgaris subsp. maritima (L.) Thell.]; Calendula incana subsp. maderensis (DC.) Ohle; Crepis divaricata (Lowe) F.W. Schultz; Hordeum marinum Huds; Lotus glaucus Sol.; Malva parviflora L.; Matthiola maderensis Lowe; Medicago minima (L.) L.; Melilotus sulcatus Desf.; Mesembryanthemum nodiflorum L.; Patellifolia pattelaris (Moq.) A.J. Scott, Ford-Lloyd \& J.T. Williams; Phalaris maderensis (Menezes) Menezes; Plantago coronopus L.; Plantago leiopetala Lowe; Rapistrum rugosum (L.) All. subsp. linnaeanum (Coss.) Rouy \& Foucaud; Senecio incrassatus Lowe; Silene vulgaris (Moench) Garcke; Spergula fallax (Lowe) E.H.L. Krause; Sonchus oleraceus L.; Suaeda vera Forssk. ex J.F. Gmel. Six of these CWR are endemic species, meaning that hold singularity as genetic resources (Table 1). Nine of these CWR (B. maritima, H. marinum, L. glaucus, $M$. minima, M. sulcatus, $P$. pattelaris, $P$. maderensis, $R$. rugosum), including $B$. patula, share the same gene pool with crop species included in the International Treaty on Plant Genetic Resources for Food and Agriculture (FAO 2009). All these facts stress the importance of $B$. patula as an umbrella species (Iriondo et al. 2012) because its populations represent the most appropriate wild populations (MAWP) for in situ conservation of several CWR. Genetic reserves most maximize non-target species richness of CWR within its borders, thereby providing umbrella protection to other CWR (Iriondo et al. 2012).

Monitoring data analysis

Data from the floristic survey and B. patula census was further analyzed statistically to determine the most suitable locations for genetic reserves implementation, using biodiversity indexes. First, the SC index was calculated. For all plots, the values averaged over the 5-year-period ranged between $\mathrm{SC}=81.98 \pm$ $1.8 \%$ and $\mathrm{SC}=95.00 \pm 0.28 \%$ (Table 3). Only plots DI5 (2015: $\mathrm{SC}=44.20 \%$ ) and CI01 (2018: SC = $71.43 \%$ ) had values lower than $75 \%$ (data not shown). The results underpin that the sampling method allowed us to detect rarer species with a high probability. Most of the plant species present in the occupancy areas were detected within the plots which are a condition for further statistical analysis application.

The average $\mathrm{E}^{\prime}$ and the respective standard deviation per each plot was calculated and displayed in Table 3. DI1 to DI5 is located on haplic calcisoils. The $\mathrm{E}^{\prime}$ values ranged from $0.59 \pm 0.14$ to $0.77 \pm 0.07$. DI6 to DI9 is in the western part of DI on eutric rocky soil (Fig. 1c). The $\mathrm{E}^{\prime}$ values ranged from $0.50 \pm 0.28$ to $0.72 \pm 0.13$. D10 to DI12 is located east of this group and grow on the same soil type. The values here ranged from $0.65 \pm 0.12$ to $0.76 \pm 0.10$. In $\mathrm{CI}$, the corresponding values were $0.42 \pm 0.23$ to $0.55 \pm 0.13$. The two lowest values of $\mathrm{E}^{\prime}$ were recorded in $\mathrm{CI}(\mathrm{CI} 20.42 \pm 0.23$ and $\mathrm{CI} 3$ $0.45 \pm 0.24$ ) and the two highest values in DI (DI3 $0.77 \pm 0.07$ and DI10 0.76 \pm 0.10 ). This index shows that overall species homogeneity is highest in DI, especially in areas where $B$. patula shows high individual counts. Therefore, DI3 and DI10 surrounding areas are proposed as the most suitable for protection as the core of the genetic reserve.

The average $\mathrm{H}^{\prime}$ per each plot over 5 years was calculated and is displayed in Table $3 . \mathrm{H}^{\prime}$ is the most widely used measure in diversity studies (Hubalek 2000). DI1-DI5 is located on haplic calcisoils (Fig. 1c). The corresponding $\mathrm{H}^{\prime}$ values ranged from $1.43 \pm 0.48$ to $2.48 \pm 0.12$ and the mean number of $B$. patula plants was 315 specimens. DI6-DI9 are in the western part of DI on eutric rocky soil (Fig. 1c). The $\mathrm{H}^{\prime}$ varied between $0.68 \pm 0.22$ and $1.74 \pm 0.54$ and relates to a mean number of $60 \mathrm{~B}$. patula plants. D10-DI12 are located east of this group and grow on the same soil type. The $\mathrm{H}^{\prime}$ ranged between $2.24 \pm 0.24$ and $2.39 \pm 0.19$ with an average number of 292 B. patula specimens. In CI, the corresponding $\mathrm{H}^{\prime}$ values were between $1.16 \pm 0.59$ and $1.56 \pm 0.40$ with an average of $58 \mathrm{~B}$. patula plants. The lowest $\mathrm{H}^{\prime}$ values were recorded in $\mathrm{CI} 1-\mathrm{CI} 3$ and are in the same order of those calculated for DI6-DI9. Again, the highest $\mathrm{H}^{\prime}$ values were obtained in the areas comprising DI1-DI5 and DI10-DI12.

Compared to $\mathrm{H}^{\prime}$, the $\mathrm{N}_{2}$ tends to depend more on the presence of a few dominant species (Hubalek 2000). $\mathrm{N}_{2}$ calculation showed that DI1-DI5 had a $\mathrm{N}_{2}{ }^{\prime}$ ranged between $2.31 \pm 0.92$ and $4.47 \pm 0.72$ (Table 3). DI6-DI9 areas had a $\mathrm{N}_{2}^{\prime}$ between $1.42 \pm 0.22$ and $2.85 \pm 0.87$. As for the area of D10-DI12, $\mathrm{N}_{2}{ }^{\prime}$ ranged from $3.63 \pm 0.86$ to $4.32 \pm 1.36$. At CI, the corresponding values of $\mathrm{N}_{2}{ }^{\prime}$ were between $1.95 \pm 0.79$ and 
$2.44 \pm 0.79$. The results showed once more a high similarity between the areas DI1-DI5 and DI10-DI12, with the highest $\mathrm{N}_{2}$ values. The same pattern appears between CI1-CI3 and DI6-DI9, in this case with the lowest values.

The relationship among $\mathrm{E}^{\prime}, \mathrm{H}^{\prime}$, and $\mathrm{N}_{2}$ indices clearly showed that the abundance of $B$. patula varies between and inside both locations (Table 3). $\mathrm{E}^{\prime}, \mathrm{H}^{\prime}$, and $\mathrm{N}_{2}$ were calculated to assess the relationship between the diversity of indices and the abundance of B. patula. Patches with lower species diversity tend to have less $B$. patula plants than those with higher species diversity. The latter is located on haplic calcisoils. It seems that B. patula is better adapted to this type of soil and that it competes well with the associated flora. DI3 appears to be the best habitat for B. patula since it indicated the highest ranking in all three indexes. As for the average number of individuals, DI1 is the one who presented the highest values.

DI6 is different from all other plots since no $B$. patula plants were ever counted. DI6 is located on haplic calcisoils close to the eutric rocky area. The species $M$. nodiflorum dominates with a high number of individuals (113 specimens) causing the smallest diversity index $\left(\mathrm{H}^{\prime}=0.68 \pm 0.22\right)$ of all plots. In CI1 $\left(\mathrm{H}^{\prime}=1.56 \pm 0.40\right), P$. coronopus is the dominating species with 236 specimens and the number of $B$. patula specimens sums up to 16 individuals, only. $M$. nodiflorum and $S$. vera are present (Table 1).

The results showed that $\mathrm{E}^{\prime}$ values for DI in 2015 differ significantly $(P>0.05)$ from all the other census years. For CI there is no significant difference between all the census years. During 2015 the plots were more homogeneous with better distribution of the number of individuals among species. Simultaneously, the increase of the number of individuals during 2017 and 2018, represented an overall decrease of $\mathrm{E}^{\prime}$ values, because some species became dominant in plots, for example, B. patula in DI1-DI5 and DI10DI12. B. patula became dominant after the control of invasive species done in the same period (data not shown). At the same time, the M. crystallinum, which is an introduced species, seems to have some invasive behavior (Marchante et al. 2008) affecting species richness and heterogeneity in all DI plots and is the cause of greater imbalance or unevenness in both islets. This aspect needs to be further analyzed to discover the causes of invasive dominancy and to evaluate to what extent $M$. crystallinum can impair $B$. patula and other CWR in both islets.

DI harbors the larger $B$. patula population and a higher number of CWR (21). Once its legal and organizational conditions match the genetic reserve quality criteria (Iriondo et al. 2008), the DI population of $B$. patula can be nominated as a MAWP for CWR in situ conservation (Maxted et al. 2015), and the site designated as a genetic reserve. In contrast, the CI population is smaller and appears to be more suitable to be exposed to genetic erosion. The observed fluctuations and effective population size of $\mathrm{N}=2917$ allow us to hypothesize that the population size could not be enough to compensate for the genetic diversity that is lost by genetic drift and mutation (Franklin 1980). Therefore, genetic monitoring of the CI population should be organized to understand if this population is a coherent reproductive unit genetically decaying or part of a metapopulation connected by geneflow.

\section{Conclusions}

The study of the demographic changes of $B$. patula and plant species diversity within the DI and CI occurrence areas provides information required to delineate and establish a genetic reserve. As the $B$. patula populations cover a rather small geographic area, the genetic reserve sites could be delineated as suggested by Frese et al. (2018). Two growing occupancy areas (DI1-DI5 and DI10-DI12) integrated into a migration area (borders are formed by DI01, DI08, DI11, and DI12), which in turn is surrounded by a transition zone, were suggested for delineation of the core of species genetic reserve. The outer (genetic) border of the genetic reserve is determined by the maximal distribution distance of $B$. patula population. These distance and distribution mechanisms however are not yet known.

The number of B. patula individuals change considerably year to year and the stochastic events can reduce the effective population size to a level that can compromise the genetic resources available for the species to recover. The generated during this work can be used as a base for comparison with further species demographic monitoring, which should occur with a periodicity established by $B$. patula genetic reserve management plan. If a steady decline in population 
size will be detected it would trigger interventions as foreseen in the management plan. The genetic relationship between DI and CI populations are not yet understood. If the DI population proves to be the initial source of genetic material and CI proves to be the founded population, respectively, without the reciprocal exchange of genetic material, conservation efforts can be focused on the DI population. If $\mathrm{CI}$ is confirmed as a population with genetically unique composition as indicated in a study of the genetic diversity of B. patula (Frese et al. 2012), the establishment of a second genetic reserve should be taken into consideration. The implementation of a genetic reserve for $B$. patula follows the European strategy for in situ conservation of CWR, which is currently under preparation by the Farmer's Pride project (http://www.farmerspride.eu/) and it could become one of the first genetic reserves in Europe once officially designated.

Acknowledgements The authors acknowledge the Forestry services and rangers of the Institute of Forests and Nature Conservation of Madeira for their support and assistance during the team fieldwork.

Funding The authors acknowledge the financial support of this work that was provided by the funding programs Life and FEDER, Madeiran Operational Program, through the projects LIFE RECOVER NATURA-LIFE12 NAT/PT/000195 and CASBio, M1420-01-0145-FEDER-000011, in in the collection, analysis, and interpretation of data; in the writing of the report; and in the decision to submit the paper for publication.

\section{Compliance with ethical standards}

Conflict of interest The authors have no competing interests to declare.

Ethical responsibilities The authors declare that the manuscript complies with the Ethical Rules applicable to this journal.

\section{References}

Adams J (2009) The holy grail of ecology: latitudinal gradients. Species Richness Patterns the Divers Life. https://doi.org/ 10.1007/978-3-540-74278-4_2

Aguiar C, Capelo J, Fontinha S, Espirito-Santo D, Jardim R, Lousã M, Rivas-Martinez S, Mesquita S, Sequeira M, de Sousa J (2004) A paisagem vegetal da Ilha da Madeira. Quercetea 6:3-200

Alves SF, Reis F, Henriques D, Freitas G, Gouveia CSS, Fernandes F, Carvalho JA, Pinheiro de Carvalho MAA (2019) Solanum trisectum Dunal: prospection, conservation and its ecogeographic baseline. Asian J Plant Sci Res 9(2):16-29

Biancardi E, Panella L, Lewellen RT (2012) Source of useful traits. In: Beta maritima, Springer, New York, NY, pp 173-223

Borges PAV, Abreu C, Aguiar AMF, Carvalho P, Jardim R, Melo I, Oliveira P, Sérgio C, Serrano ARM, Vieira P (2008) A list of the terrestrial fungi, flora and fauna of Madeira and Selvagens archipelagos. Direcção Regional do Ambiente da Madeira, Universidade dos Açores, Funchal and Angra do Heroísmo

Brehm JM, Maxted N, Ford-Lloyd BV, Martins-Louçao MA (2008) National inventories of crop wild relatives and wild harvested plants: case-study for Portugal. Genet Resour Crop Evol 55(6):779-796

Brozynska M, Furtado A, Henry RJ (2015) Genomics of crop wild relatives: expanding the gene pool for crop improvement. Plant Biotechnol J 14:1070-1085

Burnham KP, Overton WS (1979) Robust estimation of population size when capture probabilities vary among animals. Ecol 60(5):927-936

Capistrano-Gossmann GG, Ries D, Holtgrawe D et al (2016) Crop wild relative populations of Beta vulgaris allow direct mapping of agronomically important genes. Nat Commun $8(15708): 1-8$

Carvalho M, Frese L, Duarte MC, Magos Brehm J, Tavares M, Santos Guerra A, Draper D (2011) Beta patula. In: The IUCN red list of threatened species 2011: e.T162088A5532483. https://dx.doi.org/10.2305/IUCN. UK.2011-1.RLTS.T162088A5532483.en. Accessed 31 Aug 2020

Costa JC, Neto CS, Aguiar C et al (2012) Vascular plant communities in Portugal (Continental, the Azores and Madeira). Glob Geobot 2:1-180

De Hond L, Iriondo JM, Kell S (2004) Report of workshop 4: population management methodologies. PGR Forum, European Crop Wild Relative Diversity Assessment and Conservation Forum, Mahón, Menorca, Spain

De Vilmorin JL (1923) L'héredité chez la betterave cultivée. Thèse de doctorat, faculté des science, Paris, GauthierVillars et Cie, editeurs. Libraires du bureau des longitudes, de l'école polythechnique

Dempewolf H, Baute G, Anderson J, Kilian B, Smith C, Guarino L (2017) Past and future use of wild relatives in crop breeding. Crop Sci 57(3):1070-1082

Dewar AM, Haylock LA, Ecclestone PMJ (1996) Strategies for controlling aphids and virus yellows in sugar beet. In: Proceedings of the Brighton crop protection conference, pests and diseases, Brighton, England, pp 190-195

Directive H (1992) Council directive 92/43/EEC of 21 May 1992 on the conservation of natural habitats and of wild fauna and flora. Off J Eur Union 206:7-50

Drozd P (2010) Community ecology parameter calculator. ComEcoPaC http://prf.osu.cz/kbe/dokumenty/sw/ ComEcoPaC/ComEcoPaC.xls

Dwivedi SL, Upadhyaya HD, Stalker HT, Blair MW, Bertioli DJ, Nielen S, Ortiz R (2008) Enhancing crop gene pools with beneficial traits using wild relatives. Plant Breed Rev 30:179

Eizenga GC, Agrama HA, Lee FN, Jia Y (2009) Exploring genetic diversity and potential novel disease resistance 
genes in a collection of rice (Oryza spp.) wild relatives. Genet Resour Crop Evol 56:65-76

FAO (2009) International treaty on plant genetic resources for food and agriculture. FAO, Rome

FAO (2014) Genebank standards for plant genetic resources for food and agriculture. Commission on Genetic Resources for Food and Agriculture, Rome, Italy

FAO/UNESCO (1988) Soil map of the world: revised legend. FAO/UNESCO, Rome

Fontinha S, Carvalho JA (1995) Evaluation of the vascular flora of Madeira's extreme East. Bol Museu Municipal Funchal 4:263-275

Foolad MR, Panthee DR (2012) Marker-assisted selection in tomato breeding. Crit Rev Plant Sci 31:93-123

Franklin IR (1980) Evolutionary change in small populations. In: Soule ME, Wilcox BA (eds) Conservation biology: an evolutionary-ecological perspective, Sunderland, Massachusetts, pp 135-149

Frese L (2003) Sugar beets and related wild species-from collecting to utilisation. Schriften zu Genetischen Ressourcen 22:170-181

Frese L (2010) Conservation and access to sugar beet germplasm. Sugar Tech 12(3-4):207-219

Frese L, Pinheiro de Carvalho MAA (2010) Case crop study Beta (including Patellifolia) part B: EU-level case study. EU Guidelines for the creation for Beta genetic resources conservation. Work paper. ECPGR, Roma

Frese L, Nachtigall M, Enders M, Pinheiro de Carvalho MAA (2012) Beta patula Aiton: genetic diversity analysis. In: Maxted N, Lothar F, Iriondo J, Dulloo E, Ford-Lloyd BV, Pinheiro de Carvalh (eds) Agrobiodiversity conservation: securing the diversity of crop wild relatives and landraces. CABI, Wallingford, pp 45-51

Frese L, Nachtigall M, Iriondo JM, Rubio Teso ML, Duarte MC, Pinheiro de Carvalho MÂA (2018) Genetic diversity and differentiation in Patellifolia (Amaranthaceae) in the Macaronesian archipelagos and the Iberian Peninsula and implications for genetic conservation programmes. Genet Resour Crop Evol 66(1):225-241

Frese L, Nachtigall M, Iriondo JM, Teso MLR, Duarte MC, de Carvalho MÂAP (2019) Genetic diversity and differentiation in Patellifolia (Amaranthaceae) in the Macaronesian archipelagos and the Iberian Peninsula and implications for genetic conservation programmes. Genet Resour Crop Evol 66(1):225-241

Fuller DQ, Denham T, Arroyo-Kalin M et al (2014) Convergent evolution and parallelism in plant domestication revealed by an expanding archaeological record. Proc Natl Acad Sci 111(17):6147-6152

Gosselin F (2006) An assessment of the dependence of evenness indices on species richness. J Theor Biol 24(3):591-597

Gregorius HR, Gillet EM (2015) Classifying measures of biological variation. PLoS ONE 10(3):e0115312

Hajjar R, Hodgkin T (2007) The use of wild relatives in crop improvement: a survey of developments over the last 20 years. Euphytica 156:1-13

Harlan JR (1992) Origins and processes of domestication. In: Grass evolution and domestication, pp 159-175

Harlan J, de Wet J (1971) Towards a rational classification of cultivated plants. Taxon 20:509-517
Hauer M, Hansen AL, Manderyck B, Olsson Å, Raaijmakers E, Hanse B, Märländer B (2017) Neonicotinoids in sugar beet cultivation in Central and Northern Europe: efficacy and environmental impact of neonicotinoid seed treatments and alternative measures. Crop Prot 93:132-142

Heijbroek W, Roelands AJ, De Jong JH (1983) Transfer of resistance to beet cyst nematode from Beta patellaris to sugar beet. Euphytica 32(2):287-298

Heywood V, Kell S, Maxted N (2005) Global strategy for crop wild relative conservation and use. In: First international conference on crop wild relative conservation and use, PGR Forum, Agrigento, Italy

Hubalek Z (2000) Measures of species diversity in ecology: an evaluation. Folia Zool Praha 49(4):241-260

Hufford MB, Lubinksy P, Pyhäjärvi T, Devengenzo MT, Ellstrand NC, Ross-Ibarra J (2013) The genomic signature of crop-wild introgression in maize. PLoS Genet 9(5):e1003477

Instituto Português do Mar e da atmosfera. http://www.ipma.pt/ pt/. Accessed 01 Apr 2019

Iriondo JM, Ford-Lloyd B, DeHond L, Kell SP, Lefevre F, Korpelainen H, Lane A (2008) Plant population monitoring methodologies for the in situ genetic conservation of CWR. In: Iriondo JM, Maxted N, Dulloo ME (eds) Conserving plant genetic diversity in protected areas: population management of crop wild relatives. CABI, Oxfordshaire, pp 89-116

Iriondo JM, Maxted N, Kell SP, Ford-Lloyd B, Lara-Romero C, Labokas J, Pinheiro de Carvalho, MAA (2012) Identifying quality standards for genetic reserve conservation of CWR. In: Nigel (ed) Agrobiodiversity conservation: securing the diversity of crop wild relatives and landraces, pp 72-77

Kantar MB, Nashoba AR, Anderson JE, Blackman BK, Rieseberg LH (2017) The genetics and genomics of plant domestication. Bioscience 67(11):971-982

Kell SP, Maxted N, Frese L, Iriondo JM (2012) In situ conservation of crop wild relatives: a strategy for identifying priority genetic reserve sites. In: Maxted N, Dulloo ME, Ford-Lloyd BV, Frese L, Iriondo JM, PinheirodeCarvalho MAA (eds) Agrobiodiversity conservation: securing the diversity of crop wild relatives and landraces. CAB International, Wallingford, pp 7-19

Lange W, Brandenburg WA, De Bock TSM (1999) Taxonomy and cultonomy of beet (Beta vulgaris L.). Bot J Linn Soc 130:81-96

Letschert JPW (1993) Beta section Beta: biogeographical patterns of variation, and taxonomy. Dissertation, Wageningen Agricultural University

Luterbacher MC, Asher MJC, DeAmbrogio E, Biancardi E, Stevenato P, Frese L (2004) Sources of resistance to diseases of sugar beet in related Beta germplasm: I. Foliar diseases. Euphytica 139(2):105-121

Marchante H, Morais M, Freitas H, Elizabete Marchante E (2008) Guia prático para a identificação de plantas invasoras em Portugal. Imprensa da Universidade de Coimbra, Coimbra, Portugal

Maxted N, Ford-loyd BV, Hawkes JG (1997) Complementary conservation strategies. In: Maxted N, Ford-loyd BV, Hawkes JG (eds) Plant genetic conservation: the in situ approach. Chapmann \& Hall, London, pp 20-55 
Maxted M, Ford-Lloyd BV, Jury S, Kell Sh, Scholten M (2006) Towards a definition of a crop wild relative. Biodivers Conserv 15:2673-2685

Maxted N, Kell S, Toledo Á et al (2010) A global approach to crop wild relative conservation: securing the gene pool for food and agriculture. Kew Bull 65(4):561-576

Maxted N, Avagyan A, Frese L, Iriondo JM, Magos-Brehm J, Singer A, Kell SP (2015) ECPGR Concept for in situ conservation of crop wild relatives in Europe. Wild species conservation in genetic reserves working group, European Cooperative Programme for Plant Genetic Resources. Rome, Italy

Mo Hill (1973) Diversity and evenness: a unifying notion and its consequences. Ecol 54:427-432

Monteiro F, Frese L, Castro S, Duarte MC, Paulo OS, Loureiro J, Romeiras MM (2018) Genetic and genomic tools to asssist sugar beet improvement: the value of the crop wild relatives. Front Plant Sci 9:74

Morris EK, Caruso T, Buscot F, Fischer M, Hancock C, Maier TS, Socher SA (2014) Choosing and using diversity indices: insights for ecological applications from the German Biodiversity Exploratories. Ecol Evol 4(18):3514-3524

Nair KP (2019) Utilizing crop wild relatives to combat global warming. In: Advances in agronomy, Academic Press, pp 175-258

Nevo E, Chen GX (2010) Drought and salt tolerances in wild relatives for wheat and barley improvement. Plant, Cell Environ 33:670-685

Nóbrega H, Freitas G, Pinheiro de Carvalho MÂA (2020) Beta patula population assessment from 2014 to 2018 in Madeira Archipelago, Portugal. Version 1.3. University of Madeira. Sampling event dataset https://doi.org/10.15468/ j3qfk5. Accessed via GBIF.org on 2020-06-09

Parra-Quijano M, Iriondo JM, Frese L, Torres E (2012) Spatial and ecogeographic approaches for selecting genetic reserves in Europe. In: Maxted N, Dulloo ME, Ford-Lloyd BV, Frese L, Iriondo JM, PinheirodeCarvalho MAA (eds) Agrobiodiversity conservation: securing the diversity of crop wild relatives and landraces. CAB International, Wallingford, pp 20-28

Pegot-Espagnet P, Guillaume O, Desprez B et al (2019) Discovery of interesting new polymorphisms in a sugar beet (elite $\times$ exotic) progeny by comparison with an elite panel. Theor Appl Genet 132(11):3063-3078

Pinheiro de Carvalho MAA, Frese L (2011) Beta patula Aiton genetic reserve action plan. Annex 10 des Abschlussberichtes zum AEGRO-Projekt

Pinheiro de Carvalho MAA, Nóbrega H, Frese L, Freitas G, Abreu U, Costa G, Fontinha S (2010) Distribution and abundance of Beta patula Aiton and other crop wild relatives of cultivated beets on Madeira. J Kulturpflanzen 62(10):357-366

Pinheiro de Carvalho MAA, Nóbrega H, Freitas G, Fontinha S, Frese L (2012) Towards the establishment of a genetic reserve for Beta patula Aiton. In: Maxted N, Lothar F, Iriondo J, Dulloo E, Ford-Lloyd BV, Pinheiro de Carvalh MAA (eds) Agrobiodiversity conservation: securing the diversity of crop wild relatives and landraces. CAB International, Wallingford, pp 36-44

Pinheiro de Carvalho MAA, Bebeli PJ, Barata da Silva A, Bettencourt E, Slaski JJ, Dias S (2016) Agro-biodiversity. the importance of inventories in the assessment of crop diversity and its time and spatial changes. In: Ahuja M, Jain SM (eds) Genetic diversity and erosion in plants, sustainable development and biodiversity. Springer, Heidelberg, pp 130-147

Pinto R, Silva Câmara EM, Melo Ferreira MA (1992) Carta dos Solos da Ilha da Madeira. Gov Regional, Sec Reg. Economia, DRA

Pires P, Fontinha S (2008) Plantas da Ponta de São Lourenço. Edição do Serviço do Parque Natural da Madeira, Funchal, Portugal

Prescott-Allen C, Prescott-Allen R (1986) The first resource. Yale University Press, Yale

Roberge JM, Angelstam PER (2004) Usefulness of the umbrella species concept as a conservation tool. Conserv Biol 18(1):76-85

Romeiras MM, Vieira A, Silva DN et al (2016) Evolutionary and biogeographic insights on the macaronesian betaPatellifolia species (Amaranthaceae) from a time-scaled molecular. PLoS ONE 11(3):1-17

Schliephake E, Graichen K, Rabenstein F (2000) Investigations on the vector transmission of the beet mild yellowing virus (BMYV) and the Turnip yellows virus (TuYV). J Plant Dis Protect 107(1):81-87

Schliephake E, Habekuß A, Frese L (2010) Resistance of Beta patula Ait to Beet mild yellowing virus. In: CWR \& Landraces in Europe: towards the establishment of genetic reserves for crop wild relatives and landraces in Europe' and the joint meeting of the ECPGR in situ and On-farm Conservation Network and the EU project AGRI GENRES 057-AEGRO. University of Madeira, Funchal

Seiler GJ, Qi LL, Marek LF (2017) Utilization of sunflower crop wild relatives for cultivated sunflower improvement. Crop Sci 57(3):1083-1101

Spellerberg IF, Fedor PJ (2003) A tribute to Claude Shannon and a plea for more rigorous use of species richness, species diversity and the 'Shannon-Wiener' Index. Glob Ecol Biogeogr 12:177-179

Stevanato P, Chiodi C, Broccanello C, Concheri G, Biancardi E, Pavli O, Skaracis G (2019) Sustainability of the sugar beet crop. In: Sugar technology, pp 1-14

Stevens M, Hallsworth PB, Smith HG (2004) The effects of Beet mild yellowing virus and Beet chlorosis virus on the yield of UK field-grown sugar beet in 1997, 1999 and 2000. Ann Appl Biol 144(1):113-119

Traill LW, Brook BW, Frankham RR, Bradshaw CJ (2010) Pragmatic population viability targets in a rapidly changing world. Biol Conserv 143(1):28-34

Urbaniak GC, Pious S (2011) Research randomizer. Social psychology network. https://www.randomizer.org/

Vincent H, Amri A, Castañeda-Álvarez NP, Dempewolf H, Dulloo E, Guarino L, Maxted N (2019) Modeling of crop wild relative species identifies areas globally for in situ conservation. Commun Biol 2(1):136

Waples RS (2016) Tiny estimates of the $\mathrm{N}$ e/ $\mathrm{N}$ ratio in marine fishes: Are they real? J Fish Biol 89(6):2479-2504

Warschefsky E, Penmetsa RV, Cook DR, Von Wettberg EJ (2014) Back to the wilds: tapping evolutionary adaptations for resilient crops through systematic hybridization with crop wild relatives. Am J Bot 101(10):1791-1800

Wricke G (1972) Populationsgenetik. Walter de Gruyter, Berlin 
Zhang H, Mittal N, Leamy LJ, Barazani O, Song BH (2017) Back into the wild-apply untapped genetic diversity of wild relatives for crop improvement. Evol Appl 10(1):5-24
Publisher's Note Springer Nature remains neutral with regard to jurisdictional claims in published maps and institutional affiliations. 